\section{British veterinarians}

\section{Pressures for collaboration}

THE six British universities providing courses in veterinary medicine are in the throes of deciding how to meet the demand that they should teach fewer students and, at the same time, cost the central budget less. At a meeting on Wednesday this week, heads of the six schools and officials of the Royal College of Veterinary Surgeons will have tried to put a plan together. The University Grants Committee (UGC) is looking for a firm proposal by 28 January, and will otherwise draw up a scheme of its own.

The six British veterinary schools (at Bristol, Cambridge, Edinburgh, Glasgow, Liverpool and London) are all having to adjust to smaller student numbers in the wake of the third quinquennial report on veterinary manpower, commissioned by the Ministry of Agriculture, Fisheries and Food, which recommended a reduction of 10 per cent in the numbers of students recruited into veterinary medicine, from a total of 335 a year to just 300 . These reductions will take effect from the beginning of the next academic year.

Pressure from UGC arises from the high cost of teaching veterinarians in Britain. Courses last five years, following the pattern of medical education, with three "undergraduate" years of biological science and two years of clinical study, including a compulsory 26 weeks of onthe-job training. Professor E.J.L. Soulsby (Cambridge), last year's president of the Royal College and thus the initiator of the present reform, points out that the teaching of veterinarians and physicians differs in that part of the cost of medical teaching is provided indirectly by the public health services, which keep the teaching hospitals full of patients and provide for their care. Many veterinary schools have to rely on private practitioners to supply sick animals, which must then be treated and cared for out of university funds.

Several alternative proposals for reorganization are being considered, among them a plan to allow the six schools to continue in their slimmed-down form for the first three years of the standard course, but to concentrate resources required for the succeeding years at different schools, with the understanding that students would move from one place to another.

Professor I.A. Silver (Bristol) says that if the six schools have not agreed on a plan this week, it will fall to the college (of which he is president this year) to put forward a scheme acceptable to UGC. He is heartened that UGC says it will pay close attention to the quality and the amount of research in deciding which schools should be favoured.

Not all veterinarians are reconciled to

\section{DNA fingerprinting}

the conclusion that student numbers should fall by 10 per cent. Professor A. Iggo (Edinburgh) points to the potential value of novel biological techniques in the future treatment and management of domestic animals and thinks that the manpower estimates may take too little

\title{
DNA probes control immigration
}

ONE of the first uses of the technique developed at the University of Leicester by Dr Alec Jeffreys for telling the genetic identity of individuals by the use of gene probes is likely to be in the control of immigration into Britain. But the Foreign Office denied last week reports from Dacca, Bangladesh, attributing to $\mathrm{Mr}$ Timothy Eggar, Under-Secretary of State, the announcement of the introduction of an operational scheme by April this year.

The issue is potentially contentious between Britain and Bangladesh, and between the British government and its immigrant population, because of the requirements of the now strict immigration law distinguishing between blood relatives of different affinity. What appears to have happened so far is that the Home Office and the Foreign Office are jointly sponsoring a pilot study at Leicester, but have not yet decided whether to mount an operational scheme for verifying claims of kinship.

Jeffreys says, however, that the technique has already been used successfully in a number of disputed immigration cases, the first of them on the initiative of a solicitor (attorney) acting for the father of an immigrant boy whose kinship had been disputed. The solicitor had been alerted to the usefulness of the techniques by publicity following the publication of a paper last March (Jeffreys, A.L., Wilson, V. \& Thein, S.L., Nature 314, 67; 1985: see also News and Views 318, 507; 1985). The first analysis proved the claim of kinship, but the Home Office withdrew from the case so that there is as yet no legal precedent in Britain for the use of evidence of this kind.

Jeffreys says that the use of DNA fingerprinting in immigration cases is likely to be more complicated than in common paternity cases because disputed kinships may centre on suspicions that an adult is seeking to pass off a nephew as a son. Because of the high frequency of common genes among siblings, it is therefore necessary to test for a greater number of restriction polymorphisms. Even so, he estimates that it should be possible in routine cases to attain a precision of more than 99 per cent in cases of disputed account of research needs. He reckons that a third of the income of his own department may arise from research grants and contracts.

Most British schools appear, however, to accept that the overseas demand for veterinarians has shrunk substantially, even though there is still a buoyant demand from overseas schools from students with a first degree seeking graduate training and experience.

\section{kinship.}

The Home Office emphasizes that even if the technique is introduced on a regular basis in considering applications for immigration to Britain, this will be offered only on a voluntary basis. (Nothing is said of the fate of those who decline a blood sample.)

Whatever happens to the immigration project, the forensic use of the technique is likely to be widespread. The commerialization of Jeffrey's version of DNA fingerprinting is being exploited by the Lister Institute.

Romanian mathematics

\section{Absent guest at Princeton}

Dr Radu Rosu, a Romanian mathematician invited to the Princeton Institute of Advanced Studies, last week began a 12day fast to mark the beginning of the second term in which he has not been able to take up his invitation. Rosu, who was due to begin work at Princeton last September, claims that his application for a passport is blocked by the Communist Party organization of the University of Bucharest.

Dr Rosu, a geometer, began his research career at the Institute of Mathematics of the Romanian Academy of Sciences. When the academy was stripped of its institutes in the mid-1970s, and pure mathematics was virtually eliminated on utilitarian grounds, Rosu became a programmer at the computer centre of the Research Institute for the Energy Network.

In 1979, he transferred to the Institute of Mathematics at the university, where, in 1983 , he successfully defended his doctoral thesis. The invitation to Princeton seems to have been inspired by a paper with Soviet mathematician I.M. Gel'fand.

Dr Rosu is not the only Romanian mathematician resisting his government's repressive policy. Last week, Dr Mihai Botez gave an interview on French television drawing attention to (and defying), the ban on unauthorized contacts with foreigners. 